\title{
Non-Edible Vernonia galamensis Oil and Mixed Bacterial Cultures for the Production of Polyhydroxyalkanoates
}

\section{Adrian D Allen ${ }^{1,4 *}$, Folahan O Ayorinde ${ }^{2}$ and Broderick E Eribo ${ }^{3}$}

${ }^{1}$ Department of Comprehensive Sciences, Howard University, Washington, DC, USA

${ }^{2}$ Department of Chemistry, Howard University, Washington, DC, USA

${ }^{3}$ Department of Biology, Howard University, Washington, DC, USA

${ }^{4}$ NOAA Center for Atmospheric Sciences, Howard University, Washington, DC, USA

\begin{abstract}
Since the oil crisis of the 1970s much attempt has been made, albeit with varying degrees of success, to source the ideal substrate and bacteria for the production of PHA. The non-edible, naturally epoxidized seed oil from Vernonia galamensis and mixed cultures consisting of Alcaligenes latus (ATCC 29712), Cupriavidus necator (ATCC 17699), Escherichia coli (DH5a) and Pseudomonas oleovorans (ATCC 29347), were evaluated for PHA production under batch and fed-batch fermentations. PHA production, optimized by the mixed culture of E. coli and C. necator, was $0.4-19 \%$ (\%wt/wt, cdw) for batch and fed-batch fermentations. Analyses of PHA by Matrix Assisted Laser Desorption IonizationTime of Flight Mass Spectrometry (MALDI-TOF MS) and Gas Chromatography Mass Spectrometry (GC/MS) identified the 3-hydroxybutyrate $(3 \mathrm{HB})$ monomeric unit. The PHA ester bond stretching vibration $(\mathrm{C}=\mathrm{O})$, was confirmed at absorption $1740.66 \mathrm{~cm}^{-1}$, using Fourier Transform Infrared Spectroscopy (FTIR). Gel Permeation Chromatography (GPC) indicated peak molecular weights between $3.8 \times 10^{3}-1.12 \times 10^{6} \mathrm{Da}$ with melting points $\left(T_{m}\right), 60-90^{\circ} \mathrm{C}$. The data further illustrates that inedible oils could be the ideal carbon source for the production of PHA.
\end{abstract}

Keywords: Polyhydroxyalkanoate; Mixed cultures; Vernonia galamensis; Batch/fed-batch fermentation; Mass spectrometry

\section{Introduction}

The exponential growth of the human population compounded with increased consumption of non-renewable resources and pollution have reinvigorated the interest in polyhydroxyalkanoates (PHA), a class of bacterial biodegradable and biocompatible elastomers. PHA accumulates intracellularly as inclusion bodies with a diameter of 0.2 to $0.5 \mu \mathrm{m}$, and may be utilized by bacteria from 75 genera as energy/carbon storage materials [1-4]. These materials may contain about 120 different (R)-3-hydroxy acid (3HA) monomeric units with the most common being poly(3-hydroxybutyrate), $\mathrm{P}(3 \mathrm{HB})$. Blends of $\mathrm{P}(3 \mathrm{HB})$ and other hydroxyacids are classified as copolymers, which may be short chain length (scl, 3 to 5 carbon atoms) or medium chain length (mcl, 6 to 16 carbon atoms). Scl-PHAs are often stiff and brittle, whereas, mcl-PHAs are elastomeric with lower crystallization. PHAs may have molecular weights ranging from 50 to $1000 \mathrm{kDa}$ with a polydispersity $(\mathrm{PD})$ of $\approx 2$, and melting points $\left(T_{m}\right)$ of 60 to $180^{\circ} \mathrm{C}[5-7]$.

The current production of PHAs is primarily done with conventional substrates such as glucose and organic acids in conjunction with pure cultures. Although these substrates have generated PHA contents of 48 to $77 \%$ of cell dry weight ( $\mathrm{cdw}$ ), they are costly, edible and are therefore not competitive for industrial-scale production of PHA [811]. With high gross operating expenses and the resulting cost of PHA at ca. US\$ $16 / \mathrm{kg}$ versus polyethylene or polypropylene (US\$1/kg), there is an urgent need to develop and optimize strategies to economically produce the material [12].

The utilization of substrates such as plant oils may provide the solution since they contain more carbon atoms (compared to glucose), generate PHA with higher molecular masses and may produce a theoretical yield coefficient of 0.65 to $0.98 \mathrm{~g}$ PHA/g plant oil, versus 0.32-0.48 g PHA/g glucose [13-17]. Similarly, a high percentage of PHA has been generated using edible oils; therefore, non-edibles such as Vernonia galamensis oil may be a competitive alternative $[14,18$ 20]. V. galamensis is a tropical hardy plant which requires low rainfall, marginal conditions, is widely available and can be cheaply produced [21]. The unique property of V. galamensis lies in the seed oil (35-42\% of seed), which contain $72-80 \%$ low viscosity, vernolic acid (cis-12, 13 epoxy-cis-9-octadecenoic or 18:1 epoxy); and fatty acids: linoleic (12$14 \%$ ), oleic (4 to $6 \%$ ), steric (2 to $3 \%$ ), palmitic (2 to $3 \%$ ), and trace amount of arachidic acid [21]. Previously, $42.8 \mathrm{wt} \% \mathrm{P}(3 \mathrm{HB})$ and $\mathrm{P}(3 \mathrm{HB}-\mathrm{co}-3 \mathrm{HV})$ were produced from saponified $V$. galamensis under batch conditions using Cupriavidus metallidurans (formerly Alcaligenes eutrophus) [1].

The utilization of pure cultures for PHA production has been associated with several advantages and disadvantages. For example, Cupriavidus necator can utilize organic acids such as lactate, acetate and butyrate, but not glucose, fructose or xylose [22]. The bacterium produces PHA when grown on emulsified plant oil medium with gum arabic [23], and can generate a PHA concentration and content of 8.37 $\mathrm{g} / \mathrm{L}$ and $39.52 \%$ respectively when grown on condensed corn substrates [24]. The isolate will accumulate PHB with mass range $6 \times 10^{5}$ to $1 \times 10^{6}$ $\mathrm{Da}$ [4]. Nevertheless, only a few isolates can utilize the unmodified triacylglycerides (TAG), and oils must therefore be saponified $[25,26]$. Unlike C. necator, A. latus is a growth associated producer of PHA [27], utilize sucrose and can produces a $\mathrm{P}(3 \mathrm{HB})$ content and productivity of $98.7 \mathrm{~g} / \mathrm{L}(83 \%)$ and $4.94 \mathrm{~g} \mathrm{P}(3 \mathrm{HB}) / \mathrm{L} / \mathrm{h}$ respectively [28]. However, the performance of $A$. latus may be susceptible to extreme temperature, $\mathrm{pH}$, carbon to nitrogen ratio in the feed, concentration of substrates, trace elements, ionic strength, agitation intensity and dissolved oxygen level $[29,30]$. Likewise, wild type Pseudomonas oleovorans, is the best characterized mcl-PHA producer; however, it does not utilize substrates such as fructose or glucose, but grows on substrates such as fatty acids

*Corresponding author: Adrian Douglas Allen, Department of Comprehensive Sciences and NOAA Center for Atmospheric Sciences, Howard University, 415 College St. NW, Washington, DC, 20059, USA, Tel: 202-806-4172; E-mail: adriandallen@yahoo.com

Received July 22, 2014; Accepted September 18, 2014; Published September 22, 2014

Citation: Allen AD, Ayorinde FO, Eribo BE (2014) Non-Edible Vernonia galamensis Oil and Mixed Bacterial Cultures for the Production of Polyhydroxyalkanoates. Mod Chem appl 2: 136. doi:10.4172/2329-6798.1000136

Copyright: $\odot 2014$ Allen AD, et al. This is an open-access article distributed under the terms of the Creative Commons Attribution License, which permits unrestricted use, distribution, and reproduction in any medium, provided the original author and source are credited. 
or carbon sources which can undergo fatty acid de novo synthesis (n-alkanoic acids, n-alkanals and n-alkanes) [14,31-34]. Pseudomonas spp. could produce PHA with molecular weights in range $5 \times 10^{4}$ to $6 \times 10^{4} \mathrm{Da}$ [35]. PHA can only be produced by recombinant Escherichia coli (transformed with the PHA operon). The isolate affords a rapid turnover and the production of $90 \%$ (wt/wt, cdw) [36,37].

To further maximize substrate usage and optimize PHA production, mixed cultures could be an ideal alternative. Mixed culture fermentations, involving two bacteria, are characterized by the conversion of a given substrate by one bacterium to an intermediate metabolite which is subsequently used by the other to generate PHA. For example, Lactobacillus delbruckii and Cupriavidus necator can produce $\mathrm{PHB}$ concentrations of $12 \mathrm{~g} / \mathrm{L}$ by converting glucose to lactate, and lactate to $\mathrm{P}(3 \mathrm{HB})$ [38-42]. Mixed cultures may confer minimal costs, simpler facility construction, and easy recovery of material from wastes, higher growth rate of cells, decrease culture contamination and PHA accumulation $\geq 62 \% \mathrm{cdw}[43-45]$.

In this study, we investigate the suitability of saponified $V$. galamensis oil and mixed micobial cultures under batch and fed-batch fermentations, for PHA production.

\section{Materials and Methods}

\section{Microbial culture and media}

Cultures of A. latus (ATCC 29712), Cupriavidus necator (formerly R. eutropha, ATCC 17699), and P. oleovorans (ATCC 29347) were obtained from the American Type Culture Collection (ATCC, Manassas, VA, USA), and E. coli DH5a (recombinant strain with PHA operon, from Genetic Stock Center (New Heaven, Ct, USA)). These bacteria were sub-cultured in Trypticase Soy Broth (TSB) and stock cultures of each maintained on trypticase soy agar (TSA) at $4^{\circ} \mathrm{C}$. Media were prepared as outlined by the manufacturer.

The Mineral Salt Medium (MSM) used for PHA production was prepared as described elsewhere [38]. Briefly, the medium contained the following: $1.1 \mathrm{~g}\left(\mathrm{NH}_{4}\right)_{2} \mathrm{HPO}_{4}, 5.8 \mathrm{~g} \mathrm{~K}_{2} \mathrm{HPO}_{4}, 3.7 \mathrm{~g} \mathrm{KH}_{2} \mathrm{PO}_{4}, 10 \mathrm{~mL}$ $(100 \mathrm{mM}) \mathrm{MgSO}_{4}$ solution, $1 \mathrm{~mL}$ microelement solution, and distilled water to make a final volume of one liter. The following were the constituents of the micronutrient solution $(\mathrm{g} / \mathrm{L}): 2.78 \mathrm{~g} \mathrm{FeSO}_{4} .7 \mathrm{H}_{2} \mathrm{O}$, $1.98 \mathrm{~g} \mathrm{MnCl}_{2} .4 \mathrm{H}_{2} \mathrm{O}, 2.81 \mathrm{~g} \mathrm{CoSO} .7 \mathrm{H}_{2} \mathrm{O}, 1.67 \mathrm{~g} \mathrm{CaCl}_{2} .2 \mathrm{H}_{2} \mathrm{O}, 0.17 \mathrm{~g}$ $\mathrm{CuCl}_{2} .2 \mathrm{H}_{2} \mathrm{O}$ and $0.29 \mathrm{~g} \mathrm{ZnSO}_{4} .7 \mathrm{H}_{2} \mathrm{O}$. The medium was sterilized for $15 \mathrm{~min}$ at $121^{\circ} \mathrm{C} / 15 \mathrm{psi}$, and stored at $4^{\circ} \mathrm{C}$ until required. Saponified $V$. galamensis oil $(0.98 \mathrm{~g} / \mathrm{L})$ was utilized as the sole carbon source. Saponification of $V$. galamensis oil was done as mentioned elsewhere with modifications [1]. About $100 \mathrm{~mL}$ methanol and $4.95 \mathrm{~g}(0.124$ mol) sodium hydroxide were added to a $500 \mathrm{~mL}$ round bottom flask equipped with a magnetic stirring bar and a water-jacketed condenser. The mixture was refluxed until the sodium hydroxide dissolved. A mass of $10 \mathrm{~g}$ of $\mathrm{V}$. galamensis oil ( 0.011 moles, based on molecular weight of vernolic triacylglycerol) was added to the alkaline solution and refluxed with continuous stirring for $30 \mathrm{~min}$. The resulting hot mixture was then slowly added to $50 \mathrm{~g}$ ice:50 $\mathrm{g}$ water and the resulting off-white semisolid crushed, filtered and air dried.

\section{Batch/fed-batch fermentation, extraction and purification of PHA}

The isolates A. latus, C. necator, P. oleovorans and E. coli DH5 $\alpha$ (recombinant strain with PHA operon) were utilized under batch and fed-batch fermentation. Under batch fermentation, aliquots of $100 \mathrm{~mL}$ Mineral Salt Medium (MSM) were inoculated with $5 \mathrm{~mL}$ of $2 \times 10^{8} \mathrm{CFU} /$ $\mathrm{mL}$ of each bacterium and fermentation conducted at $25^{\circ} \mathrm{C}, 120 \mathrm{rpm}$ for $96 \mathrm{~h}$ on a Lab-line Environ incubator (USA) or a gyrotory shaker (New Brunswick, N.J., USA). Cells were harvested via centrifugation, lyophilized, weighed, and the polymer extracted and analyzed. Fedbatch fermentation was carried out as previously outlined for $24 \mathrm{~h}$ with subsequent additions of $20 \mathrm{~mL}$ MSM every $12 \mathrm{~h}$ for $96 \mathrm{~h}$ and, the resulting fermentation broths treated as before. All batch and fed batch fermentations were repeated five times. Furthermore, the effect of $\mathrm{pH}$ (4.5 and 8.5) and degree of agitation ( 90 and $240 \mathrm{rpm}$ ) on productivity was determined. Fermentations were carried out as mentioned previously under batch and fed-batch conditions and the resulting fermentation broths treated accordingly.

Throughout fermentations, $500 \mu \mathrm{l}$ broth was evaluated for PHA accumulation using Nile blue $\mathrm{A}$ and the hypochlorite assay [46-48]. Smears were stained with Nile blue A $(1 \%)$ at $55^{\circ} \mathrm{C}$ for $10 \mathrm{~min}$ and slides washed with water and $8 \%$ acetic acid for 1 min then evaluated. Similarly, for the hypochlorite assay, a $200 \mu \mathrm{l}$ broth was mixed with 4.8 $\mathrm{mL}$ of $5.25 \%$ sodium hypochlorite (Clorox) then incubated at $38^{\circ} \mathrm{C}$ for $40 \mathrm{~min}$. Lipids in solution were determined from the optical density at $436 \mathrm{~nm}$.

Fermentation broths were centrifuged (Sorvall RC-5, Dupont Instruments, Newtown, CT) for $15 \mathrm{~min}$ at $15,000 \mathrm{rpm}, 4^{\circ} \mathrm{C}$ and pellets re-suspended by washing once with $20 \mathrm{ml}$ Tris- $\mathrm{HCl}$ buffer $(\mathrm{pH}$ 7.2). Pellets were lyophilized $\left(-50^{\circ} \mathrm{C}\right.$ and $25 \mathrm{mmHg}$ ) (LABCONCO Freeze Dryer 5, Kansas City, Missouri), and $100 \mathrm{mg}$ refluxed with $100 \mathrm{~mL}$ chloroform for $3 \mathrm{~h}$, then filtered (Whatman cellulose extraction thimble, $43 \times 123 \mathrm{~mm}$ single thickness, Aldrich, Milwaukee, WI, USA). The resulting oily film was purified using methanol and chloroform and the precipitate dried and stored $\left(-4^{\circ} \mathrm{C}\right)$ for further analysis.

The purity of the polymer was determined as mentioned previously [46]. Briefly, $0.1 \mathrm{mg}$ polymer was mixed with $10 \mathrm{~mL}$ concentrated sulphuric acid (98\%) and the mixture incubated at $97^{\circ} \mathrm{C}$ for $10 \mathrm{~min}$. Optical density was measured between 220 to $250 \mathrm{~nm}$, and melting point determined by using a Fisher Johns melting point apparatus (Fisher Scientific Company, USA).

\section{PHA analyses}

The purified material was analyzed using Matrix Assisted Laser Desorption-Time of Flight Mass Spectrometry (MALDI-TOF MS), Gas Chromatography/Mass Spectrometry (GC/MS), Fourier Transform Infrared Spectroscopy (FTIR) and Gel Permeation Chromatography (GPC).

\section{MALDI-TOF MS}

All samples (mixed and commercial) were base transesterified by reacting $1 \mathrm{mg}$ sample with $100 \mu \mathrm{l}$ dichlormethane, vortexing for 1 min, and $4 \mu \mathrm{l}$ of $25 \%$ sodium methoxide in methanol and $5 \mu \mathrm{l}$ glacial acetic acid added. The reaction was allowed to proceed for $30 \mathrm{~min}$. 2,5-dihydrobenzoic acid (2,5 DHB, 99\%), the matrix, was prepared by dissolving $162 \mathrm{mg} \mathrm{2,5} \mathrm{DHB}$ in $1 \mathrm{~mL}$ tetrahydrofuran (THF). Cationized oligomers were analyzed by mixing $20 \mu \mathrm{l}$ of the mixture with $50 \mu \mathrm{l}$ matrix, and applying $1 \mu \mathrm{l}$ to MALDI target (Bruker Reflex III MALDI-TOF mass spectrophotometer). Runs were performed with the following parameters: accelerating voltage, $20 \mathrm{kV}$; grid voltage, 56 to $99 \%$; guide wire voltage 0 to $0.3 \%$; positive high resolution reflective mode with summation of 150 transients. Three runs were performed for each sample.

\section{GC/MS}

GC/MS analysis of samples was done by base transesterification 
Citation: Allen AD, Ayorinde FO, Eribo BE (2014) Non-Edible Vernonia galamensis Oil and Mixed Bacterial Cultures for the Production of Polyhydroxyalkanoates. Mod Chem appl 2: 136. doi:10.4172/2329-6798.1000136

Page 3 of 6

to their monomers as outlined before [1]. An Agilent Technologies 6890 N Network GC System (CA, USA) interfaced directly to an Agilent Technologies 5973 Inert Mass Selective Detector was used to generate data. Electronic pressure through a capillary column was used to maintain a constant helium flow of $35 \mathrm{~cm} / \mathrm{s}$. The following parameters were included in the GC program: temperature was held at $50^{\circ} \mathrm{C}$ for 2 min then increased to $300^{\circ} \mathrm{C}$ at a rate of $20^{\circ} \mathrm{C} / \mathrm{min}$, then held at $300^{\circ} \mathrm{C}$ for a total of $14 \mathrm{~min}$. The auxiliary temperature was set at $250^{\circ} \mathrm{C}$ and the column flow rate at 1.2. A solvent delay time of 4 min was applied to each sample. About $1 \mu \mathrm{l}$ of the transesterified sample was injected into the GC/MS instrument and a Hewlett-Packard PC integration program used to calculate the peak areas and percentages of the monomeric components of the polymer. Data analysis was performed using the NIST02 database.

\section{Fourier Transform Infrared Spectroscopy (FT-IR)}

FTIR (Perkin Elmer Spectrum 100, Version 6.3.2) was used for analysis of PHA. Samples for analysis were purified as mentioned before, dissolved in $100 \mu \mathrm{l}$ chloroform and 20-30 $\mu \mathrm{l}$ added to sample crystal window. The following parameters were included in the instrument program: resolution, $4.0 \mathrm{~cm}^{-1}$, scan speed $0.2 \mathrm{~cm} / \mathrm{s}$, range $4000-650 \mathrm{~cm}^{-1}$ and 4 scans for each run. Runs were done in duplicate.

\section{Gel Permeation Chromatography (GPC)}

Gel permeation chromatography was used to ascertain the apparent number-average $\left(M_{n}\right)$, weight-average $\left(M_{w}\right)$, molecular masses and polydispersity (PD, $\mathrm{M}_{\mathrm{w}} / \mathrm{M}_{\mathrm{n}}$ ) of the PHA. Samples ( $1 \mathrm{mg}$ ) were dissolved in 50:50 tetrahydrofuran (THF, HPLC grade) chloroform (HPLC grade), and filtered $(0.2 \mu \mathrm{m})$. A Waters" $2690 \mathrm{GPC}$ separation module equipped with a Waters 2410 refractive detector and Polymer laboratories C-Linear mixed-bed size exclusion columns $(2 \times 300 \mathrm{~mm} / 7.5 \mathrm{~mm})$ was used. The degasser was set at continuous with a pressure of $0.5 \mathrm{psi}$, and the lines at $100^{\circ} \mathrm{C}$. Polystyrene standards A with peak molecular weight range of 5460 to 96,000 and B, 2930 to 50,400 (Polyscience Corp. Warrington, PA, USA) with low polydispersity were used to generate a chromatogram and calibration curve. THF was used as the eluant at a flow rate of $0.7 \mathrm{~mL} / \mathrm{min}$ at $35^{\circ} \mathrm{C}$.

\section{Results}

\section{Fermentation, extraction and purification of PHA}

The resulting dry cell weight and PHA yield under standard conditions, variations in $\mathrm{pH}$ and dissolved oxygen, and the resulting melting points and peak molecular weights are shown in Table 1. Higher yields were observed under batch compared to fed-batch fermentations.

The Nile blue A and hypochlorite assays indicated the accumulation of PHA during fermentations. For the former assay, the characteristic orange fluorescence was visible at a wavelength of $460 \mathrm{~nm}$ (data not shown). Furthermore, a maximum absorbance at $235 \mathrm{~nm}$ (data not shown), was shown for the crotonic acid assay of the purified PHA.

\section{PHA Analyses}

MALDI-TOF MS: MALDI-TOF mass spectrometry was used to identify the oligomers resulting from base trans-esterification of mixed culture polymers (Figure 1). Generally, mass spectra showed mostly sodium $[\mathrm{M}+\mathrm{Na}]^{+}$and potassium $[\mathrm{M}+\mathrm{K}]^{+}$adducts attached to the oligomeric chains of the PHA. The mass difference between adjacent peaks was an average of $86(\mathrm{Da})$ and indicated the presence of the PHA repeat unit [- $\left.\mathrm{OCH}\left(\mathrm{CH}_{3}\right) \mathrm{CH}_{2} \mathrm{CO}-\right]$. These are clusters of isotopically resolved peaks of the same oligomer, but consisting of different end groups. The ion at $m / z 1156.58$ is identified as a sodiated dodecamer with an olefinic end group i.e. $\left[\mathrm{CH}_{3} \mathrm{CH}=\mathrm{CHC}(\mathrm{O}) \mathrm{OCH}_{3}\left(\mathrm{CH}_{3}\right)\right.$ $\left.\mathrm{CH}_{2} \mathrm{C}(\mathrm{O})_{12} \mathrm{OCH}_{3}-\mathrm{Na}\right]^{+}$. The potassium adduct of this oligomer is shown at $\mathrm{m} / z 1174.1$.

Gas chromatography/ mass spectrometry (GC/MS): GC/MS was used for the identification of the monomeric/oligomeric composition of the isolated polymers. Overall, the gas chromatograms illustrate the various signature peaks for the methyl- $\beta$-hydroxybutyrate produced from base hydrolysis of the polymer (Figure 2). The electron impact mass spectrum shows ions at $\mathrm{m} / z 85,100$ and $117(+1)$. These were identified as $\left\{\mathrm{CH}_{3} \mathrm{CHCH}_{2} \mathrm{COO}-\right\}, \quad\left\{\mathrm{CH}_{3} \mathrm{CHCH}_{2} \mathrm{COOCH}_{3}\right\}$ and $\left\{\mathrm{CH}_{3} \mathrm{CH}\{\mathrm{OH}\} \mathrm{CH}_{2} \mathrm{COOCH}_{3}\right\}$ respectively. These signatures were identical to those produced from the base hydrolyzed commercial $\mathrm{P}(3 \mathrm{HB})$ with average elution time of $6.6 \mathrm{~min}$. Identity was confirmed by the NIST02 database.

Fourier Transform Infrared Spectroscopy (FTIR): FTIR was utilized for the determination of functional and/or other groups found within PHA (Figure 3). The observed infrared absorption for the mixed cultures of A. latus and Cupriavidus necator were $3019.98(=\mathrm{C}-\mathrm{H}$ and $\left.=\mathrm{CH}_{2}\right), 2917.41,2849.44\left(\mathrm{CH}_{3}, \mathrm{CH}_{2}\right.$ and $\left.\mathrm{CH}\right), 1740.66(\mathrm{C}=\mathrm{O}) ; P$. oleovorans and Cupriavidus necator, 2849.32 and $2917.26\left(\mathrm{CH}_{3}, \mathrm{CH}_{2}\right.$, $\mathrm{CH}), 1261.41(\mathrm{O}-\mathrm{C})$; and pure cultures of $P$. oleovorans, $3019.83(=\mathrm{C}$ $\mathrm{H}$ and $\left.=\mathrm{CH}_{2}\right), 2921.43,2850.85\left(\mathrm{CH} 3, \mathrm{CH}_{2}\right.$ and $\left.\mathrm{CH}\right), 1728.85(\mathrm{C}=\mathrm{O})$, $1459.24\left(\mathrm{CH}_{2}, \mathrm{CH}_{3}\right)$; Cupriavidus necator, 2849.89, $2918.07\left(\mathrm{CH}_{3}, \mathrm{CH}_{2}\right.$ and $\mathrm{CH}), 1740.66(\mathrm{C}=\mathrm{O}), 1261.14(\mathrm{O}-\mathrm{C})$ and $1017.89(-\mathrm{OH})$. The FTIR spectrum for the commercial $\mathrm{P}(3 \mathrm{HB}),\left(-\mathrm{COCH}_{2} \mathrm{CHCH}_{3}\right)_{\mathrm{n}}$ identified infrared absorption at $\mathrm{cm}^{-1} 3020.12$ (straight, $=\mathrm{CH}$ ), 1724.07 (saturated aldehyde, $\mathrm{C}=\mathrm{O}$ ), 1281.25 (acids straight, $\mathrm{O}-\mathrm{C}$ ), 1133.04, 1057.16, 980.40 $(\mathrm{OH})$.

Gel-Permeation Chromatography (GPC): GPC was used to determine the weight number average mass $\left(M_{n}\right)$, peak molecular weight (MP), molecular weight $\left(\mathrm{M}_{\mathrm{w}}\right)$ and polydispersity $\left(\mathrm{M}_{\mathrm{w}} / \mathrm{M}_{\mathrm{n}}\right)$ of the polymer produced from saponified $V$. galamensis oil (Table 1).

\begin{tabular}{|c|c|c|c|c|c|c|}
\hline \multirow[b]{2}{*}{ pH 7} & \multicolumn{2}{|c|}{$\begin{array}{c}\text { A. latus + C. necator } \\
\operatorname{cdw}(\mathrm{mg} / \mathrm{L}) \text { PHA(\%wt/wt, cdw) }\end{array}$} & \multicolumn{2}{|c|}{$\begin{array}{c}\text { P. oleovorans + C. necator } \\
c d w(m g / L) \text { PHA(\%wt/wt, cdw) }\end{array}$} & \multicolumn{2}{|c|}{$\begin{array}{c}\text { E. coli }+ \text { C. necator } \\
\operatorname{cdw}(m g / L) P H A(\% w t / w t, c d w)\end{array}$} \\
\hline & $920 / 820$ & $11 / 12$ & $1160 / 860$ & $10.3 / 11.6$ & $1320 / 620$ & $19 / 16$ \\
\hline $\mathrm{pH} 4$ & $382 / 520$ & $7.8 / 3$ & $264 / 460$ & $2.3 / 2.2$ & $286 / 560$ & $0.3 / 2.7$ \\
\hline $\mathrm{pH} 8$ & $496 / 500$ & $2 / 2$ & $536 / 560$ & $2.6 / 2.3$ & $444 / 540$ & $2.7 / 18$ \\
\hline DO 90 & $240 / 240$ & $2 / 3$ & $280 / 320$ & $3.2 / 2.2$ & $180 / 320$ & $3.3 / 3$ \\
\hline DO 240 & $302 / 220$ & $0.5 / 0.4$ & $18 / 10$ & $6 / 10$ & $304 / 280$ & $1.6 / 1.7$ \\
\hline${ }^{\mathrm{d}} \mathrm{PM}$ (Da) & \multicolumn{2}{|c|}{$1.2 \times 10^{5}$} & \multicolumn{2}{|c|}{$3.7 \times 10^{5}$} & \multicolumn{2}{|c|}{$3.9 \times 10^{4}$} \\
\hline${ }^{\mathrm{e}} \boldsymbol{T}_{m}\left({ }^{\circ} \mathrm{C}\right)$ & \multicolumn{2}{|c|}{$80-90$} & \multicolumn{2}{|c|}{$61-65$} & \multicolumn{2}{|c|}{$61-70$} \\
\hline
\end{tabular}

${ }^{a}$ Culture, A. latus (ATCC 29712), C. necator (ATCC 17699), E. coli (DH5a) and P. oleovorans (ATCC 29347); bbatch fermentation, cell dry weight, cdw; ${ }^{\circ}$ Fedbatch fermentation; ${ }^{d} \mathrm{PM}(\mathrm{Da})$, Peak molecular weight in Daltons; ${ }^{\mathrm{e}} T_{m}\left({ }^{\circ} \mathrm{C}\right)$, melting temperature of the polymer in Celsius. Polystyrene standards $\mathrm{A}$, with molecular weight 1300 $377,400 \mathrm{Da}$, and standard B, with molecular weight 500-210,500 Da, were used to derive standard curve

Table 1: Yields and properties for PHA produced by mixed bacterial cultures grown on saponified $V$. galamensis oil under batch and fed-batch fermentation. 


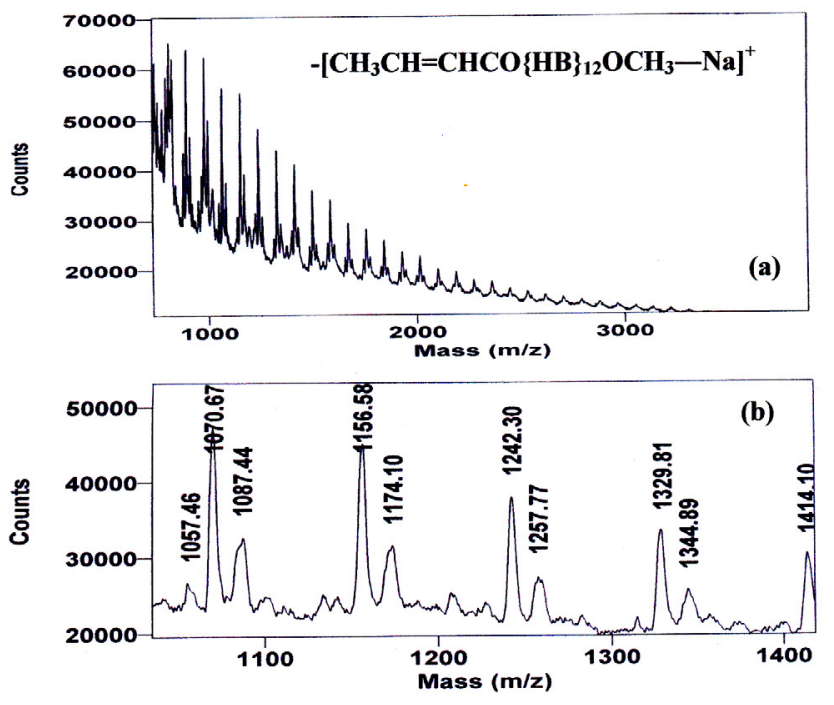

Figure 1: (a) Representative positive ion MALDI-TOF mass spectra of partially transesterified saponified $V$. galamensis oil PHA produced by mixed culture of Escherichia coli and Ralstonia eutropha (b) Expanded view of 'a' between $\mathrm{m} / \mathrm{z} 1057$ and 1400 . Peak at $\mathrm{m} / \mathrm{z} 1156.58$ indicate the sodiated 3-HB oligomer $\mathrm{m} / \mathrm{z} 1156.58\left[\mathrm{CH}_{3} \mathrm{CH}=\mathrm{CHCO}\{\mathrm{HB}\}_{12} \mathrm{OCH}_{3}-\right.$ $\mathrm{Na}]^{+}$and the potassium adduct of this oligomer is shown at 1174.10 $\left[\mathrm{CH}_{3} \mathrm{CH}=\mathrm{CHCO}\{\mathrm{HB}\}_{12} \mathrm{OCH}_{3}-\mathrm{K}\right]^{+}$. Runs were done in reflection mode with 2,5-dihydrobenzoic acid (2,5 DHB, 99\%) and 120 transients. Analysis was accomplished using a Bruker Reflex III MALDI-TOF mass spectrophotometer with accelerating voltage, $20 \mathrm{kV}$, positive high resolution reflective mode with 150 transients.

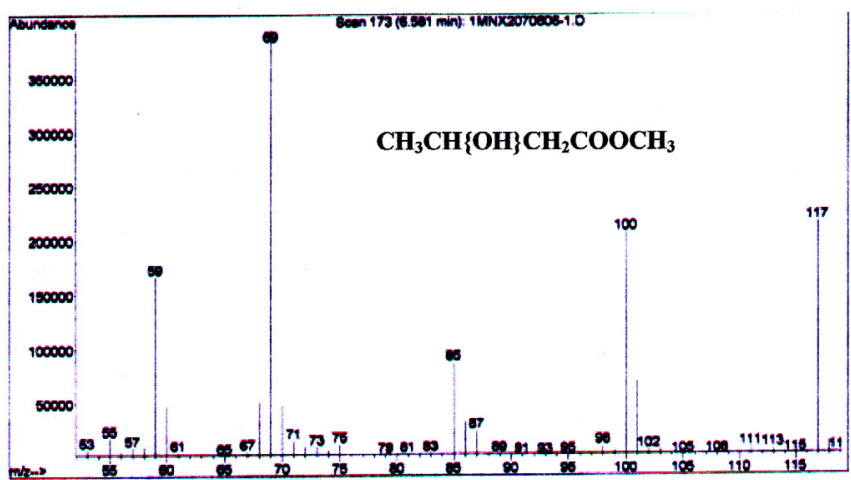

Figure 2: Electron-impact mass spectrum of trans esterified polymer produced by mixed culture cultivated on saponified Vernonia galamensis oil. The methylester of hydroxybutyric acid is indicated by the ion at $\mathrm{m} / \mathrm{z}$ $117\left\{\mathrm{CH}_{3} \mathrm{CH}\{\mathrm{OH}\} \mathrm{CH}_{2} \mathrm{COOCH}_{3}\right\}$. The ions at $\mathrm{m} / \mathrm{z} 100\left\{\mathrm{CH}_{3} \mathrm{CHCH}_{2} \mathrm{COOCH}_{3}\right\}$ and $86\left\{\mathrm{CH}_{3} \mathrm{CHCH}_{2} \mathrm{COO}\right\}$ are fragment from the ion at $\mathrm{m} / \mathrm{z} 117$. Data was ascertained using an Agilent Technologies 6890N Network GC System (CA, USA) interfaced directly to an Agilent Techonologies 5973 Inert Mass Selective Detector with program: temperature was held at $50^{\circ} \mathrm{C}$ for $2 \mathrm{~min}$ then increased to $300^{\circ} \mathrm{C}$ at a rate of $20^{\circ} \mathrm{C} / \mathrm{min}$, then held at $300^{\circ} \mathrm{C}$ for a total of $14 \mathrm{~min}$. The auxiliary temperature was set at $250^{\circ} \mathrm{C}$ and the column flow rate at 1.2 .

The peak molecular weights for polystyrene standard A ranged from 1300 to $377400 \mathrm{Da}$ while that of standard B ranged from 580 to 210 $500 \mathrm{Da}$ were automatically used to generate a standard curve (data not shown). Analysis of all chromatogram illustrates peak molecular weight between $3.8 \times 10^{3}-1.12 \times 10^{6} \mathrm{Da}$.

\section{Discussion}

In the current study, saponified $V$. galamensis oil was utilized by mixed bacterial cultures under batch and fed-batch fermentations to produce $19 \%$ (wt/wt, cdw) PHA with peak molecular weight in range $10^{3}$ to $10^{6} \mathrm{Da}$. This yield shows some improvement over previous studies wherein between 5.7 to $34.4 \%$ PHA was produced by pure culture of Pseudomonas spp. cultivated on rice, canola, sunflower, soybean, corn and hydrolyzed linseed oils $[6,18]$. Polymer accumulation, indicated by Nile blue A (Nile blue sulphate, basic blue) is consistent with previous reports and was a good indicator since stained PHA granules are easily identifiable by their characteristic orange fluorescence [16,47]. Neutral lipids do not affect identification of PHA since these lipids are liquids at the staining temperature $\left(55^{\circ} \mathrm{C}\right)$ and have no affinity for Nile red (the oxidized form of Nile blue); therefore, cell membranes and other lipid containing cell components do not absorb enough dye to yield a detectable fluorescence at a wavelength of $460 \mathrm{~nm}$ [46]. Although this data was supported by the hypochlorite assay, the assay has been associated with several disadvantages which include severe degradation of polymer during digestion; only polymer in the native form of the lipid can be measured; the temperature and incubation time of the cell/ hypochlorite mix must be precisely controlled and the suspension must be homogeneous [49-52].

Nevertheless, the methods were good predictors for the optimal points for PHA accumulation and cell dry weight (cdw). The resultant cdw was inversely proportional to PHA yield under both batch and fed-batch fermentation for all mixed cultures, and was dependent on Cupriavidus necator which is known to accumulate PHA when nutrients such as nitrogen and phosphorus are completely depleted from the environs [44]. The resulting lower PHA contents under batch and fed-batch modes indicates that bacterial growth rate under alkaline conditions is characterized by a logarithmic increase in viable cells [50]; therefore, an initial $\mathrm{pH}$ of 6.0 to 7.5 is ideal for microbial growth [52]. Similarly, variations in agitation had a significant effect on the growth of all mixed cultures and subsequently the PHA yields under batch and fed-batch fermentations. This further confirms the observation that high bacteria growth was inversely proportional to PHA yield. The consumption of oxygen is related to $\mathrm{CO}_{2}$ production and ATP generation; therefore, manipulating the availability of oxygen

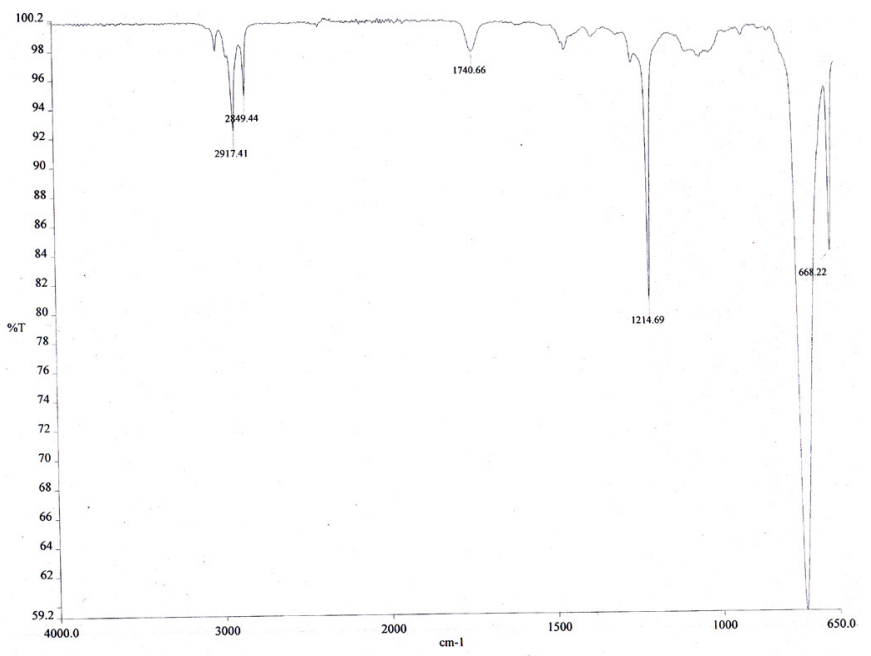

Figure 3: Representative Fourier Transform Infrared Radiation (FTIR) spectrum of PHA, produced by mixed culture of $A$. latus (ATCC 29712) + $R$. eutropha (ATCC 17699), cultured with saponified Vernonia galamensis oil as sole carbon source. The following parameters were included in the instrument program: resolution, $4.0 \mathrm{~cm}^{-1}$, scan speed $0.2 \mathrm{~cm} / \mathrm{s}$, range 4000 $650 \mathrm{~cm}^{-1}$ and 4 scans for each run. Runs were done in duplicate at RTP. 
will contribute to overall fermentation yields i.e. PHB concentration, content and productivity, but not cell concentration [53,54]. Oxygen limitation (which can be generated by increasing the rpm) was previously shown to increase the PHB contents in fed-batch cultures containing recombinant E. coli with a PHB content of $80 \%$ [55]. Likewise, a cdw of $54 \mathrm{~g} / \mathrm{L}(46 \% \mathrm{PHB})$ was produced by Azotobacter chroococcum under oxygen limitation, and $71 \mathrm{~g} / \mathrm{L} \mathrm{dcw} \mathrm{(20 \%} \mathrm{PHB)}$ under non-limiting oxygen conditions [56]. Deficiencies in oxygen, i.e., low oxidative capacity, could increase the rate of $\mathrm{P}(3 \mathrm{HB})$ production in Cupriavidus necator and other microbes [53]. Assimilative activities such as protein and glycogen synthesis, and other cellular components are enhanced when oxygen supply is sufficient; however, if oxygen supply is curtailed, such activities will be minimized, thereby, contributing to increase production of PHA [5]. Suppression of assimilative activities contributes to the accumulation of NADH which inhibits the enzymes citrate synthase and isocitrate dehydrogenase in the tricarboxylic acid cycle (TCA) [35]. As a result, acetyl-CoA no longer enters the TCA cycle at the same rate and is instead converted to acetoacetyl-CoA by 3-ketothiolase. Therefore, increasing agitation speeds will limit the dissolved oxygen in the fermentor and contributes to increased PHB concentration, content and productivity, but not cell concentration [55].

The identity and purity of the extracted polymeric material was initially confirmed by spectrometric measurement $(235 \mathrm{~nm})$ of the $\alpha$, $\beta$-unsaturated bond of crotonic acid (2-butenoic acid), produced by the reaction of PHA with sulphuric acid [46]. Further analyses indicated $T_{m}$ between 61 to $90^{\circ} \mathrm{C}$ for all mixed culture PHA, compared to that derived from commercial material, 135 to $150^{\circ} \mathrm{C}$. It has been suggested that the usual $T$ for a PHA consisting primarily of the homopolymer, $\mathrm{P}(3 \mathrm{HB})$, occurs between 174 to $179^{\circ} \mathrm{C}$; however, this decreases dramatically if the homopolymer is coupled with varying percentages of other hydroxyacids such as hydroxyvalerate (HV), hydroxyhexanoate (HHx), among others $[4,35]$. For example, a copolymer containing $30 \mathrm{~mol} \%$ $3 \mathrm{HV}$ had a $T_{m}$ of $143^{\circ} \mathrm{C}[21,39]$; and $T_{m}$ range of 163 to $174^{\circ} \mathrm{C}$ (maximum at $\left.172^{\circ} \mathrm{C}\right)$, for the copolymer, $\mathrm{P}(3 \mathrm{HB}-\mathrm{co}-1 \mathrm{~mol} \% \mathrm{HV})$, produced using C. necator on saponified V. galamensis oil [1].

Further analysis of mixed culture PHA using MALDITOF MS identified only the HB oligomeric unit at $\mathrm{m} / z 1156.40$ $\left[\mathrm{CH}_{3} \mathrm{CH}=\mathrm{CHCO}\{\mathrm{HB}\}_{12} \mathrm{OCH}_{3}-\mathrm{Na}\right]^{+}$with isotopic fragments containing sodium and potassium adducts at 1174.1 $\left[\mathrm{CH}_{3} \mathrm{CH}=\mathrm{CHCO}\{\mathrm{HB}\}_{12} \mathrm{OCH}_{3}-\mathrm{K}\right]^{+}$respectively. This observation was further confirmed by GC/MS i.e., only the 3-HB oliogomer was identified in the polymer. This finding is unusual, since P. oleovorans is a known producer of medium chain length PHA. Thus, copolymers, if produced, may have been utilized by the isolate for growth and/or concentrations were beyond the threshold of the instrument. FTIR identified the PHA marker absorption band at $1740.66 \mathrm{~cm}^{-1}$ i.e., the carbonyl $(\mathrm{C}=\mathrm{O})$ ester bond stretching vibration [57]. However, absorption at $1740.66 \mathrm{~cm}^{-1}$ and 1738.28 were previously shown to be representative of medium chain length hydoxyacids (mclHA), while the absorption at 1728.85 and $1724.07 \mathrm{~cm}^{-1}$, observed for the commercial homopolymer ( $\mathrm{HB})$ in this study, for the $\mathrm{HB}$ unit and was similar to the previous study [58]. The evaluation of polymers by GPC indicated a peak molecular weight range of $1.2 \times 10^{5}$ to $1.12 \times 10^{6} \mathrm{Da}$. It was not possible to determine the uniformity of the polymers, since their polydispersities were not generated by the instrument. Other fragments eluted above $20 \mathrm{~min}$ had peak molecular weights in range 19 to $1000 \mathrm{Da}$ and polydispersities between 1 and 1.4. Although immediate evidence is lacking, these fragments may be impurities, the lower molecular weight polymer called complexed PHA or other fragments from polymer deterioration. The environmental conditions, method of isolation and the microbe used for fermentation, can adversely affect the molecular weight of polymers [35]. For example, Cupriavidus necator has been shown to accumulate $\mathrm{PHB}$ with peak molecular weight in the range $6 \times 10^{5}$ to $1 \times 10^{6} \mathrm{Da}$, while Pseudomonas spp. $5 \times 10^{4}$ to $6 \times 10^{4} \mathrm{Da}[5,36]$ The biosynthesis of mcl-PHA or other PHA copolymers is problematic for E. coli, due to the difficulty of drawing PHA precursors from the fatty acid metabolic pathways. Nevertheless, the current data suggests that the molecular weight of resultant polymers was dependent on bacteria used and culture conditions.

The current data illustrate that non-edible oils such as V.galamensis and mixed bacterial cultures could be optimized to generate PHAs with ideal melting points and molecular weights. Further studies are underway to evaluate other non-edible oils with these mixed cultures.

\section{Acknowledgement}

We would like to express our sincere gratitude to Dr. Emmanuel O. Akala and Dr. Simeon Adesina, Howard University School of Pharmacy and Ms. Nikki Handy, Howard University, Department of Chemistry for their help with data acquisition using Gel Permeation Chromatography (GPC) and Fourier Transform Infrared Spectroscopy (FTIR) respectively.

\section{References}

1. Ayorinde FO, Saeed KA, Price E, Morrow A, Collins WE, et al. (1998) Production of poly-( $\beta$-hydroxybutyrate) from saponified Vernonia galamensis oil by Alcaligenes eutrophus. Journal of Industrial Microbiology and Biotechnology 21: $46-50$

2. Alias Z, Tan IK (2005) Isolation of palm oil-utilising, polyhydroxyalkanoate (PHA)-producing bacteria by an enrichment technique. Bioresour Technol 96: 1229-1234.

3. Luengo JM, García B, Sandoval A, Naharro G, Olivera ER (2003) Bioplastics from microorganisms. Curr Opin Microbiol 6: 251-260.

4. Madison LL, Huisman GW (1999) Metabolic engineering of poly(3hydroxyalkanoates): from DNA to plastic. Microbiol Mol Biol Rev 63: 21-53.

5. Salehizadeh H, Van Loosdrecht MC (2004) Production of polyhydroxyalkanoates by mixed culture: recent trends and biotechnological importance. Biotechnol Adv 22: 261-279.

6. Silva-Queiroz SR, Silva LF, Pradella JG, Pereira EM, Gomez JG (2009) $\mathrm{PHA}(\mathrm{MCL})$ biosynthesis systems in Pseudomonas aeruginosa and Pseudomonas putida strains show differences on monomer specificities. J Biotechnol 143: 111-118.

7. Sudesh K, Abe H, Doi Y (2000) Synthesis, structure and properties of polyhydroxyalkanoates: biological polyesters. Progress in Polymer Science 25: 1503-1555.

8. Nath A, Bhat S, Devle J, Desai AJ (2005) Enhanced production of 3-hydroxybutyric acid (3-HB) by invivo depolymerization of polyhydroxybutyric acid in 3-HB dehydrogenase mutants of Methylobacterium sp. ZP24. Ann Microbiol 55: 107-111.

9. Ren Q, Grubelnik A, Hoerler M, Ruth K, Hartmann R, et al. (2005) Bacterial poly(hydroxyalkanoates) as a source of chiral hydroxyalkanoic acids. Biomacromolecules 6: 2290-2298.

10. Shahid S, Mosrati R, Ledauphin J, Amiel C, Fontaine P, et al. (2013) Impact of carbon source and variable nitrogen conditions on bacterial biosynthesis of polyhydroxyalkanoates: evidence of an atypical metabolism in Bacillus megaterium DSM 509. J Biosci Bioeng 116: 302-308.

11. Sun Z Ramsay J, Guay M, Ramsay B (2009) Enhanced yield of medium-chainlength polyhydroxyalkanoates from nonanoic acid by co-feeding glucose in carbon-limited, fed-batch culture. J Biotechnol 143: 262-267.

12. Scheller J, Conrad U (2005) Plant-based material, protein and biodegradable plastic. Curr Opin Plant Biol 8: 188-196.

13. Chen GQ, Zhang G, Park SJ, Lee SY (2001) Industrial scale production of poly(3-hydroxybutyrate-co-3-hydroxyhexanoate). Appl Microbiol Biotechnol 57 : 50-55

14. He W, Tian W, Zhang G, Chen GQ, Zhang Z (1998) Production of novel polyhydroxyalkanoates by Pseudomonas stutzeri 1317 from glucose and soybean oil. FEMS Microbiology Letters 169: 45-49. 
15. Kahar $\mathrm{P}$, Tsuge $\mathrm{T}$, Taguchi $\mathrm{K}$, Doi $\mathrm{Y}$ (2004) High yield production of polyhydroxyalkanoates from soybean oil by Ralstonia eutropha and its recombinant strain. Polymer Degradation and Stability 83: 79-86.

16. Tan IKP, Kumar KS, Theanmalar M, Gan SN, Gordon III B (1997) Saponified palm kernel oil and its major free fatty acids as carbon substrates for the production of polyhydroxyalkanoates Pseudomonas putida PGA1. Applied Microbiology and Biotechnology 47: 207-211.

17. Tsuge T (2002) Metabolic improvements and use of inexpensive carbon sources in microbial production of polyhydroxyalkanoates. J Biosci Bioeng 94 579-584

18. Casini E, de Rijk TC, de Waard P, Eggink G (1997) Synthesis of poly(hydroxyalkanoate) from hydrolyzed linseed oil. Journal of environmental polymer degradation 5: 153-158.

19. Saeed KA, Eribo BE, Ayorinde FO, Collier L (2002) Characterization of copolymer hydroxybutyrate/hydroxyvalerate from saponified vernonia, soybean, and "spent" frying oils. J AOAC Int 85: 917-924.

20. Thakor N, Trivedi U, Patel KC (2005) Biosynthesis of medium chain length poly(3-hydroxyalkanoates) (mcl-PHAs) by Comamonas testosteroni during cultivation on vegetable oils. Bioresour Technol 96: 1843-1850.

21. Baye T, Becker HC (2005) Genetic variability and interrelationship of traits in the industrial oil crop Vernonia galamensis. Euphytica 142: 119-129.

22. Shi H, Shiraishi M, Shimizu K (1997) Metabolic flux analysis for biosynthesis of poly( $\beta$-hydroxybutyric acid) in Alcaligens eutrophus from various carbon sources. Journal of Fermentation and Bioengineering 84: 579-587.

23. Budde CF, Riedel SL, Hübner F, Risch S, Popović MK, et al. (2011) Growth and polyhydroxybutyrate production by Ralstonia eutropha in emulsified plant oil medium. Appl Microbiol Biotechnol 89: 1611-1619.

24. Chakraborty P, Muthukumarappan K, Gibbons WR (2012) PHA productivity and yield of Ralstonia eutropha when intermittently or continuously fed a mixture of short chain fatty acids. J Biomed Biotechnol 2012: 506153.

25. Cromwick AM, Foglia T, Lenz RW (1996) The production of polyhydroxyalkanoates from tallow. Applied Microbiology and Biotechnology 46: 464-469.

26. Solaiman DK, Ashby RD, Foglia TA (2001) Production of polyhydroxyalkanoates from intact triacylglycerols by genetically engineered Pseudomonas. Appl Microbiol Biotechnol 56: 664-669.

27. Hrabak O (1992) Industrial production of poly- $\beta$-hydroxybutyrate. FEMS Microbiology Letters 103: 251-255.

28. Lee SY, Choi J (1999) Production and degradation of polyhydroxyalkanoates in waste management. Waste Management 19: 133-139.

29. Wang F, Lee SY (1997) Poly(3-Hydroxybutyrate) Production with High Productivity and High Polymer Content by a Fed-Batch Culture of Alcaligenes latus under Nitrogen Limitation. Appl Environ Microbiol 63: 3703-3706.

30. Yamane T, Chen X, Ueda S (1996) Growth-Associated Production of Poly(3Hydroxyvalerate) from n-Pentanol by a Methylotrophic Bacterium, Paracoccus denitrificans. Appl Environ Microbiol 62: 380-384.

31. Fritzsche K, Lenz RW, Fuller RC (1990) Production of unsaturated polyesters by Pseudomonas oleovorans. Int J Biol Macromol 12: 85-91.

32. Preusting $\mathrm{H}$, Nijenhuis A, Witholt B (1990) Physical characteristics of poly(3hydroxyalkanoates) and poly(3-hydroxyalkenoates) produced by Pseudomonas oleovorans grown on aliphatic hydrocarbons. Macromolecules 23: 4220-4224.

33. Sandoval A, Arias-Barrau E, Bermejo F, Cañedo L, Naharro G, et al. (2005) Production of 3-hydroxy-n-phenylalkanoic acids by a genetically engineered strain of Pseudomonas putida. Appl Microbiol Biotechnol 67: 97-105.

34. Timm A, Steinbüchel A (1990) Formation of polyesters consisting of mediumchain-length 3-hydroxyalkanoic acids from gluconate by Pseudomonas aeruginosa and other fluorescent pseudomonads. Appl Environ Microbiol 56 3360-3367.

35. Anderson AJ, Dawes EA (1990) Occurrence, metabolism, metabolic role, and industrial uses of bacterial polyhydroxyalkanoates. Microbiol Rev 54: 450-472.

36. Lee SY, Chang HN (1995) Production of poly(3-hydroxybutyric acid) by recombinant Escherichia coli strains: genetic and fermentation studies. Can J Microbiol 41 Suppl 1: 207-215.

37. Li R, Zhang H, Qi Q (2007) The production of polyhydroxyalkanoates in recombinant Escherichia coli. Bioresour Technol 98: 2313-2320.
38. Ganduri VSRK, Ghosh S, Patnaik PR (2005) Mixing control as a device to increase $\mathrm{PHB}$ production in batch fermentations with co-cultures of Lactobacillus delbrueckii and Ralstonia eutropha. Process Biochemistry 40: 257-264.

39. Katoh T, Yuguchi D, Yoshii H, Shi H, Shimizu K (1999) Dynamics and modeling on fermentative production of poly (beta-hydroxybutyric acid) from sugars via lactate by a mixed culture of Lactobacillus delbrueckii and Alcaligenes eutrophus. J Biotechnol 67: 113-134.

40. Tohyama M, Takagi S, Shimizu K (2000) Effects of controlling lactate concentration and periodic change in DO concentration on fermentation characteristics of a mixed culture of Lactobacillus delbrueckii and Ralstonia eutropha for PHB production. Journal of Bioscience and Bioengineering 89: 323-328.

41. Delgenes JP, Escare MC, Laplcae JM, Moletta R, Navarro JM (1998) Biological production of industrial chemicals, i.e. xylitol and ethanol, from lignocelluloses by controlled mixed culture systems. Industrial Crops and Products 7: 101-111.

42. Fang HHP, Liu Y (2000) Intracellular polymers in aerobic sludge of sequencing batch reactors. Journal of Environmental Engineering 126: 732-738.

43. Iwamoto $Y$, Satoh H, Mino T, Matsuo T (1994) Production of biodegradable plastic PHA by excess sludge from anaerobic-aerobic activated sludge process. Proc Environ Eng Res 31: 305-314.

44. Lemos PC, Viana C, Salgueiro EN, Ramos AM, Crespo JPSG, et al. (1998) Effect of carbon source on the formation of polyhydroxyalkanoates (PHA) by a phosphate-accumulating mixed culture. Enzyme and Microbial Technology 22: $662-671$

45. Saito Y, Soejima T, Tomozawa T, Doi Y, Kiya F (1995) Production of biodegradable plastics from volatile acids using activated sludge. J Environ Syst Eng 521: 145-154.

46. Ostle AG, Holt JG (1982) Nile blue A as a fluorescent stain for poly-betahydroxybutyrate. Appl Environ Microbiol 44: 238-241.

47. Wendlandt KD, Geyer W, Mirschel G, Al-Haj Hemidi F (2005) Possibilities for controlling a PHB accumulation process using various analytical methods. J Biotechnol 117: 119-129.

48. Law JH, Slepecky RA (1961) Assay of poly-beta-hydroxybutyric acid. J Bacterio 82: $33-36$

49. Serafim LS, Lemos PC, Levantesi C, Tandoi V, Santos H, et al. (2000) Methods for detection and visualization of intracellular polymers stored by polyphosphate-accumulating microorganisms. J Microbiol Methods 51: 1-18.

50. Padan E, Bibi E, Ito M, Krulwich TA (2005) Alkaline pH homeostasis in bacteria new insights. Biochim Biophys Acta 1717: 67-88.

51. Braunegg G, Lefebvre G, Genser KF (1998) Polyhydroxyalkanoates, biopolyesters from renewable resources: physiological and engineering aspects. J Biotechnol 65: 127-161.

52. Kim HM, Ryu KE, Bae K, Rhee YH (2000) Purification and characterization of extracellular medium-chain-length polyhydroxyalkanoate depolymerase from Pseudomonas sp. RY-1. J Biosci Bioeng 89: 196-198.

53. Kim BS (2000) Production of poly(3-hydroxybutyrate) from inexpensive substrates. Enzyme Microb Technol 27: 774-777.

54. Kim BS, Chang HN (1998) Production of poly (3-hydroxybutyrate) from starch by Azotobacter chroococcum. Biotechnology letters 20: 109-112.

55. Randriamahefa S, Renard E, Guérin P, Langlois V (2003) Fourier transform infrared spectroscopy for screening and quantifying production of PHAs by Pseudomonas grown on sodium octanoate. Biomacromolecules 4: 1092-1097.

56. Hong K, Sun S, Tian W, Chen GQ, Huang W (1999) A rapid method fo detecting bacterial polyhydroxyalkanoates in intact cells by Fourier transform infrared spectroscopy. Applied Microbiology and Biotechnology 51: 523-526.

57. Khanna S, Srivastava AK (2005) Recent advances in microbia polyhydroxyalkanoates. Process Biochemistry 40: 607-619.

58. Grothe E, Moo-Young M, Chisti Y (1999) Fermentation optimization for the production of poly( $\beta$-hydroxybutyric acid) microbial thermoplastic. Enzyme and Microbial Technology 25: 132-141. 